\title{
Breast Engorgement
}

National Cancer Institute

\section{Source}

National Cancer Institute. Breast Engorgement. NCI Thesaurus. Code C92746.

A painful swelling of the breasts due to accumulation of milk in blocked lactating ducts. 